Canadian Journal of Soil Science Revue canadienne de la science du sol

\title{
GREENHOUSE GAS DYNAMICS IN A TREE-BASED INTERCROPPING SYSTEM COMPARED TO AN ORGANIC CONVENTIONAL SYSTEM
}

\begin{tabular}{|r|l|}
\hline Journal: & Canadian Journal of Soil Science \\
\hline Manuscript ID & CJSS-2016-0081.R1 \\
\hline Manuscript Type: & Special Issue Paper (Please select below) \\
\hline Date Submitted by the Author: & 08-Nov-2016 \\
\hline Complete List of Authors: & $\begin{array}{l}\text { Cuellar Castillo, Mario Alberto; Université Laval, Soil science department } \\
\text { Allaire, Suzanne; Université Laval, Horticultural Research Center } \\
\text { Lange, Sebastien; Université Laval, Horticultural Research Center } \\
\text { Bradley, Robert; Université de Sherbrooke, Biologie } \\
\text { Parsons, William; Université de Sherbrooke, Biologie } \\
\text { Rivest, David; Universite du Quebec en Outaouais, Sciences Naturelles } \\
\text { Cogliastro, Alain; Université Laval, Phytologie }\end{array}$ \\
\hline Keywords: & Agroforestry, Carbon dioxide, Nitrous oxide, Soil physics, Trees \\
\hline
\end{tabular}

\section{SCHOLARONE ${ }^{\text {M }}$ \\ Manuscripts}




\section{GREENHOUSE GAS DYNAMICS IN A TREE-BASED INTERCROPPING SYSTEM COMPARED TO AN ORGANIC CONVENTIONAL SYSTEM}

Mario A. Cuéllar ${ }^{1}$, Suzanne E. Allaire ${ }^{1 *}$, Sébastien F. Lange ${ }^{1}$, Robert L. Bradley², William F.J. Parsons $^{2}$, David Rivest ${ }^{3}$, Alain Cogliastro ${ }^{4}$

${ }^{1}$ Département des sols, Université Laval, 2480 rue Hochelaga, Québec, QC, G1V 0A6, Canada

${ }^{2}$ Université de Sherbrooke, 2500 boul. de l'Université, Sherbrooke, QC, J1K 2R1, Canada

${ }^{3}$ Université du Québec en Outaouais, 283 boul. Alexandre-Taché, Gatineau, QC, J8X 3X7, Canada ${ }^{4}$ Jardin botanique de Montréal, 4101 Sherbrooke Est, Montréal, QC, H1X 2B2, Canada

*Corresponding author 


\begin{abstract}
Tree-based intercropping (TBI) system has been suggested as an alternative to conventional monocropping $(\mathrm{CM})$ for decreasing overall GHG emissions. However, little is known about the advantages of TBI compared with organic CM system with low fertilizer inputs. This project compared $\mathrm{CO}_{2}$ and $\mathrm{N}_{2} \mathrm{O}$ dynamics in replicated TBI and CM in Saint-Paulin (Québec, Canada), established about 12 years prior to this study under organic production, with horse manure and pruning residues as soil amendments. An experimental field, using a complete randomized block design, was instrumented in both systems. A five-point sampling transect was established between tree rows in each of the six plots. Surface $\mathrm{CO}_{2}$ and $\mathrm{N}_{2} \mathrm{O}$ fluxes, $\mathrm{CO}_{2}$ and $\mathrm{N}_{2} \mathrm{O}$ soil concentrations and other physico-chemical properties were analyzed at 0.125 and $0.25 \mathrm{~m}$ depths over two growing seasons. $\mathrm{CO}_{2}$ and $\mathrm{N}_{2} \mathrm{O}$ concentrations in TBI soil were similar to or lower than in $\mathrm{CM}$ soil. Lower $\mathrm{CO}_{2}$ and $\mathrm{N}_{2} \mathrm{O}$ emissions suggest TBI would decrease overall GHG mitigation, even when compared with organic production with low fertilizer inputs, in addition to its potential for carbon sequestration in wood and other advantages, which are not discussed in this study.
\end{abstract}

Keywords: Agroforestry, Carbon dioxide, Nitrous oxide, Soil physics, Trees, Emission fluxes

\title{
INTRODUCTION
}

Agroforestry has received renewed attention brought by continuing global change, considering the inclusion of trees could potentially decrease carbon (C) loss in agricultural ecosystems, both through increased carbon sequestration and through decreased C emissions (Quinkenstein et al., 2009; Nair 2012; Winans et al., 2014). Tree growth influences soil organic carbon (SOC) content and $\mathrm{CO}_{2}$ 
dynamics (Dixon et al., 1994; Schoeneberger et al., 2012). Trees act as natural long-term sinks for atmospheric $\mathrm{CO}_{2}$ by capturing and storing carbon in their woody tissues, and by transferring fixed carbon to various soil pools through their annual litter fall as well as through fine root decomposition and turnover (Oelbermann et al., 2004; Quinkenstein et al., 2009). Carbon sequestration resulting from the implementation of agroforestry practices could potentially restore SOC levels in agricultural fields within a period of 20 to 50 years (Montagnini and Nair 2004; Lorenz and Lal 2014). Under agroforestry systems, carbon storage may reach $9 \mathrm{Mg} \mathrm{C} \mathrm{ha}^{-1}$ in semiarid, $21 \mathrm{Mg} \mathrm{C}^{-1}$ in sub-humid, $50 \mathrm{Mg} \mathrm{C} \mathrm{ha}{ }^{-1}$ in humid, and $63 \mathrm{Mg} \mathrm{C} \mathrm{ha}^{-1}$ in temperate ecoregions (Schroeder, 1993). Trees can influence soil temperature and moisture regimens under adjacent crops through the wind-buffering, shading and transpiration effects they exert on water and heat dynamics (Davis and Norman, 1998). Thus, trees can have a strong local influence on carbon cycling in the agricultural landscape, which includes mitigating rates of $\mathrm{CO}_{2}$ emissions and, potentially, rates of other GHGs (i.e., $\mathrm{CH}_{4}$ and $\mathrm{N}_{2} \mathrm{O}$ ).

Among the various types of agroforestry systems, tree-based intercropping (TBI) has been shown to increase soil C sequestration (Quinkenstein et al., 2009; Bambrick et al., 2010; Udawatta and Jose, 2012) and to decrease $\mathrm{N}_{2} \mathrm{O}$ emissions (Beaudette et al. 2010), when compared with conventional monocropping (CM) systems. In southern Canada, TBI systems can reduce soil $\mathrm{N}_{2} \mathrm{O}$ emissions by 1.2 $\mathrm{kg} \mathrm{ha}^{-1} \mathrm{y}^{-1}$ compared with $\mathrm{CM}$, through tree uptake of the excess $\mathrm{N}$ (nitrate) fertilizer applied to row crops (Evers et al., 2010). Moreover, this nitrogen eventually returns to the soil in the form of slowly decomposing leaf litter and green manure (tree pruning) inputs for the next crops. TBI systems may also indirectly mitigate $\mathrm{N}_{2} \mathrm{O}$ emissions, whereby the presence of trees in crop fields favours greater soil moisture extraction, which would reduce local temporary anoxic conditions leading to denitrification. Agricultural $\mathrm{N}_{2} \mathrm{O}$ emissions are frequently associated with inefficient inorganic- $\mathrm{N}$ applications, and are produced through coupled microbial nitrification-denitrification processes in these soils (Bouwman et 
al., 2002; Desjardins et al., 2010). Application of TBI to cropping systems should result in a decrease of synthetic fertilizer demand and in lower $\mathrm{N}_{2} \mathrm{O}$ emissions (Thevathasan et al., 2012).

We expected gas dynamics in agroforestry systems would differ from those of CM agricultural practices due to the influence of trees. The effects of trees are shaped by land, which in turn influence a variety of factors, including crop and tree species, climate and time-since-installation, together with management practices. For example, tree species used in temperate TBI systems can differ in their litter production and chemistry, conditions sufficient to cause divergence in soil $\mathrm{C}$ and $\mathrm{N}$ dynamics (Mungai and Motavalli, 2006). Yet, direct and indirect interactions between trees and soil parameters on GHG dynamics $\left(\mathrm{CO}_{2}, \mathrm{~N}_{2} \mathrm{O}\right)$ and on soil $\mathrm{C}$ in agroforestry systems are not well documented in Canada. Even less is known about $\mathrm{CO}_{2}$ and $\mathrm{N}_{2} \mathrm{O}$ dynamics under organic production, regardless of whether they are TBI or CM systems.

The aforementioned studies have included GHG responses of treatment plots that were amended with mineral fertilizers - a routine practice in industrially cropped land areas across Canada. Over a 25-year period, total nitrogen applications (including manure N) per hectare of farmland in Canada rose from an average $24 \mathrm{~kg} \mathrm{~N} \mathrm{ha}^{-1}$ in 1981 to $36 \mathrm{~kg} \mathrm{~N} \mathrm{ha}^{-1}$ in 2006 (Yang et al., 2011). Synthetic inorganic fertilizers have come to dominate total $\mathrm{N}$ inputs, i.e., from $41.3 \%$ (1981) to $56.9 \%(2006)$ over the same period, and with no sign of decreasing trend.

Crop production in agroforestry can be managed under a wide range of agricultural practices, but producers in agroforestry systems often employ low-impact techniques, such as organic production using manure inputs, either to protect their trees or because they believe in environmentally sustainable farming (Jordan, 2004). Given that mineral fertilizers are a major source of soil GHGs, it remains unclear whether tree-based intercropping would provide additional environmental benefits compared with CM in organically fertilized soils or organically managed systems. The objective of the study was 
to compare in situ $\mathrm{N}_{2} \mathrm{O}$ and $\mathrm{CO}_{2}$ emissions and soil gas concentrations over two growing seasons under TBI and CM crop production, which employed organic fertilizer (horse manure) applications. We made the hypothesis that under organic production with few external inputs, trees will have a small but significant effect on carbon and nitrogen dynamics in soil.

\section{MATERIALS AND METHODS}

\section{Site description}

The study was conducted over two growing seasons (2012-2013) in a TBI system (established in 2004) near St-Paulin, Québec ( $\left.46^{\circ} 27^{\prime} \mathrm{N}, 72^{\circ} 59^{\prime} \mathrm{W}\right)$. The site was originally installed to test the Ecosys Modelling program of a comprehensive mathematical model of diverse natural and managed ecosystems (Wang et al., 2011). This site serves to collect input data among different sites chosen for agroforestry systems. It was also used to test the effect of trees on water dynamics in agroforestry systems (Rousseau et al., 2012).

The land is relatively flat (1\% slope). The soil was classified as a Dystric Brunisol (Lamontagne and Nolin, 1997; FAO equivalent, Dystric Cambisol), with a sandy loam texture (82\% sand, $12 \%$ silt, $6 \%$ clay) and a $\mathrm{pH}_{\text {water }}$ of 5.5. $\mathrm{pH}$ varied little across the field and increased by 0.5 units after liming. Annual temperature average is $4^{\circ} \mathrm{C}$ in the region which receives $1113 \mathrm{~mm} \mathrm{y}^{-1}$ of precipitation (Environment Canada 2013). During the 2012 growing season, average monthly air temperatures were $12.1^{\circ} \mathrm{C}$ (May), $18.7^{\circ} \mathrm{C}$ (June), $21.0^{\circ} \mathrm{C}$ (July), $20.3^{\circ} \mathrm{C}$ (August), $14.3^{\circ} \mathrm{C}$ (September), and $9.1{ }^{\circ} \mathrm{C}$ (October). For the same months in 2013, average air temperatures were respectively 14.7, 16.5, 20.7, $18.9,13.7$ and $10.1^{\circ} \mathrm{C}$.

The experimental layout was a complete randomized block design with two agricultural systems (TBI vs CM) replicated in four blocks, three of which were used for studying GHG dynamics (Fig. 1). Rows of hybrid poplars (Populus deltoides W. Bartram ex Humphry Marshall $\times$ P. nigra L.) alternated 
with rows of high-value hardwood $(\mathrm{HVH})$ species (Quercus rubra L., Prunus serotina Ehrhart). Tree rows were $12 \mathrm{~m}$ apart and planted in spring 2004 to form the TBI system. Poplar cuttings were planted at $2 \mathrm{~m}$ intervals (238 stems ha $\left.{ }^{-1}\right)$; hardwood seedlings were planted every $3 \mathrm{~m}\left(134 \mathrm{stems} \mathrm{ha}^{-1}\right)$. A 2 mwide uncultivated strip was maintained within each tree row, including a $1.2 \mathrm{~m}$-wide band of black polyethylene mulch. Each plot $(60 \mathrm{~m} \times 24 \mathrm{~m})$ was bounded on either side by a row of hybrid poplars (HP), with two alleys of crops in the middle, which were separated by one row of hardwood species (Fig. 1).

Crop rotations in the alleys consisted of oat (Avena sativa L.)-buckwheat (Fagopyrum esculentum Moench) in 2004-2005, buckwheat-canola (Brassica napus L.) in 2006, and buckwheat in 2007. The annual crops were followed by 4 years (2008 to 2012) of forage production (Trifolium pratense L. and Phleum pratense L. mixture), and by buckwheat in 2013. CM plots (30 $\mathrm{m} \times 24 \mathrm{~m}$; no trees, Fig. 1) used the same crop rotation as the TBI plots. Annual tree maintenance included pruning and thinning; two out of every three poplars were cut in 2012. The soils were tilled from 2004 to 2009. Tillage using a disk harrow in the spring incorporated manure and unharvested residues into the soil $(0-8 \mathrm{~cm})$, within 1-2 $\mathrm{m}$ of the tree stems. Moldboard plowing (to $15-\mathrm{cm}$ depth) occurred in fall after the annual crop harvest, but no tillage was performed after seeding forages. Horse manure (solid manure mixed with bedding; $\mathrm{C} / \mathrm{N}$ ratio of 25:1) was broadcasted on the surface in spring 2004 and 2007 at a rate of $30 \mathrm{Mg}$ $\mathrm{ha}^{-1}$ with a rear-discharge manure spreader prior to tillage. In November 2007 and 2012, lime $(\mathrm{CaCO} 3$, $5 \mathrm{Mg} \mathrm{ha}^{-1}$ ) was incorporated into the soil by plowing. No other fertilizers were applied. The site was managed under organic production practices; only horse manure and pruning residues were applied annually as soil amendments. Deep soil tillage (up to $40 \mathrm{~cm}$ depth) was completed only once, in fall 2012. 


\section{In situ instrumentation and measurements}

Thirty sampling points were established along transects (6 transects x 5 sampling points) in each block, perpendicular to the edge of the field (tree rows in TBI plots). One point was located on the HVH tree line in TBI plots $(0 \mathrm{~m})$, two points at $4 \mathrm{~m}$ on either side of $\mathrm{HVH}(-4 \mathrm{vs} 4 \mathrm{~m})$ and 2 points at $10 \mathrm{~m}$ on either side of $\mathrm{HVH}(-10$ vs $10 \mathrm{~m})$. The latter points were $2 \mathrm{~m}$ from the poplar lines (Fig. 1). In the CM plots, sampling points were located at the same distances from the plot edge. Transects were aligned from West to East going from one hybrid poplar row $(-10 \mathrm{~m}$ point), then across the high-value hardwoods $(0 \mathrm{~m})$, and finally to the second hybrid poplar row $(10 \mathrm{~m})$.

Soil gas concentrations $\left(\mathrm{CO}_{2 \text {-soil }}, \mathrm{N}_{2} \mathrm{O}_{\text {-soil }}\right)$ were measured using sealed $50 \mathrm{~cm}$-long access tubes made of PVC tubing $(0.5 \mathrm{~cm} \mathrm{ID)}$ and vertically inserted to $0.125 \mathrm{~m}$ and $0.25 \mathrm{~m}$ depths. Soil temperature $(\mathrm{T})$ was monitored using type-T (copper-constantan) thermocouples at the same depths, while volumetric water content (WC) was measured using 0.15 metre-long TDR (Time-Domain Reflectometry) probes at the same depths. WC was calculated with Topp's equation (Topp et al., 1980). Soil parameters were measured 6 times from May to October 2012 and 9 times from April to November 2013 . Temperatures ranged from 4.5 to $34{ }^{\circ} \mathrm{C}$, with means of $14{ }^{\circ} \mathrm{C}$ in 2012 and $17{ }^{\circ} \mathrm{C}$ in 2013 respectively. Still in 2013 , WC averaged $0.20 \mathrm{~m}^{3} \mathrm{~m}^{-3}$ at $0.125 \mathrm{~m}$ and $0.16 \mathrm{~m}^{3} \mathrm{~m}^{-3}$ at $0.25 \mathrm{~m}$ depths. Based on soil water retention curves (using tension tables), the lowest WC values indicated that the soil reached the temporary wilting point for short periods for both years.

Intact cores (0.06 m dia. $x 0.06 \mathrm{~m}$ height) were taken at every sampling point along transects at the same depths as for temperature and moisture measurements to determine soil bulk density $(\mathrm{BD}, \mathrm{Mg}$ $\mathrm{m}^{-3}$; Blake and Hartge, 1986) and saturated hydraulic conductivity $\left(\mathrm{K}_{\mathrm{sat}}\right)$. $\mathrm{K}_{\mathrm{sat}}$ was measured using constant head permeametry (Klute and Dirksen, 1986). Bulk density varied from 1.3 to $1.5 \mathrm{Mg} \mathrm{m}^{-3}$, with a mean value of $1.4 \mathrm{Mg} \mathrm{m}^{-3}$, which indicated relatively high soil densities. $\mathrm{K}_{\text {sat }}$ values ranged from 
3.6 to $30 \mathrm{~m} \mathrm{~d}^{-1}$, which meant that some water would form puddles on the soil surface after intense rainfall events. The soils were otherwise relatively well drained.

Additional soil was sampled at $0.125 \mathrm{~m}$ and $0.25 \mathrm{~m}$ depths at every sampling point to measure total organic carbon content $\left(\mathrm{C}_{\text {Total }}\right)$, which was determined using dry combustion (Skjemstad and Baldock, 2007), and soluble organic carbon concentrations $\left(\mathrm{C}_{\text {soluble }}\right)$, which were quantified colorimetrically using a coupled Mn reduction-organic carbon oxidation reaction (Bartlett and Ross, 1988). Inorganic nitrogen pools $\left(\mathrm{NO}_{3}^{-}\right.$and $\mathrm{NO}_{2}^{-} ; \mathrm{NH}_{4}^{+}$not detectable) in additional soil aliquots were quantified colorimetrically (Griess-Ilosvay reaction) following $\mathrm{KCl}$ extraction (Keeney and Nelson, 1982). $\mathrm{C}_{\text {Total, }}$ $\mathrm{C}_{\text {soluble, }} \mathrm{NO}_{3}{ }^{-}$and $\mathrm{NO}_{2}{ }^{-}$were only measured in samples taken on July 5, 2013.

\section{In situ soil gas concentrations and flux measurements}

Gas access tubes were flushed through the septa using gas-tight hypodermic syringes (10 mL, BectonDickinson 309643, Franklin Lakes, NJ) about 2 h prior to sampling. Gas samples (10 mL) were drawn using the same syringes and immediately inserted into gas-tight vials (10 mL model 5182-0838, Agilent Technologies, Wilmington, DE) that had been previously purged and capped with aluminum seals (20 mm, 224178-01, Wheaton, Milleville, NJ) and rubber butyl septa (Wheaton 224 100-202), which were specifically selected for $\mathrm{CO}_{2}$ and $\mathrm{N}_{2} \mathrm{O}$ measurements (Lange et al. 2008).

Surface gas emissions $\left(\mathrm{CO}_{2 \text {-flux, }} \mathrm{N}_{2} \mathrm{O}_{\text {-flux }}\right)$ were measured using dynamic closed chambers (Rochette and McGinn, 2005) directly installed on the soil surface. They were made of PVC (0.15 m radius $\mathrm{x}$ $0.22 \mathrm{~m}$ height). Ten chambers were installed simultaneously to minimize measurement duration. They were rotated to complete the 30 sampling points. Gas samples were taken at $0,2.5,5,7.5,10,15,20$, and $30 \mathrm{~min}$. These samples $(10 \mathrm{~mL})$ were drawn using the same syringes, septa and vials used for sampling the soil atmosphere. Soil gas concentrations $\left(\mathrm{CO}_{2 \text {-soil, }} \mathrm{N}_{2} \mathrm{O}_{\text {-soil }}\right)$ and fluxes $\left(\mathrm{CO}_{2 \text {-soil, }} \mathrm{N}_{2} \mathrm{O}_{\text {-soil }}\right)$ 
were measured 6 times over the 2012 growing season (24 May to 11 October) and 9 times during the 2013 growing season (6 May to 23 September).

$\mathrm{CO}_{2}$ and $\mathrm{N}_{2} \mathrm{O}$ concentrations were quantified using a gas chromatograph (model 6890N, Agilent Technologies) equipped with a 30 m HP-PLOT-Q column (19095P-QO4PT), and a TCD detector in 2012, and TCD and ECD detectors in 2013. The carrier gas was helium (UH-T 5.0, Praxair, Danbury, CT) in 2012 and $\mathrm{Ar}_{-} \mathrm{CH}_{4}\left(95: 5 \mathrm{P}-5\right.$, Praxair) in 2013. $\mathrm{CO}_{2 \text {-flux }}$ and $\mathrm{N}_{2} \mathrm{O}_{\text {-flux }}\left(\mu \mathrm{g} \mathrm{m} \mathrm{m}^{-2} \mathrm{~s}^{-1}\right)$ were calculated from linear portions of the chamber concentration vs time curves (Rochette and McGinn, 2005).

\section{Statistical analyses}

Descriptive statistics of all variables were calculated using PROC UNIVARIATE (v. 9.3, SAS Institute 2012). Prior to analysis, data was subjected to Box-Cox transformation (Box and Cox 1964) when required, to improve the normality of their distributions.

Treatment responses were analyzed with three-way mixed-effects RMANOVA (MIXED procedure, with repeated measures). Variance-covariance structures of the data were determined by model selection using the Akaike information criterion (Akaike, 1974). Fixed effects were treatment (2 levels), distance (3 levels), depth (3 levels) and time (3 levels), while the random effect was block. Correlations among $\mathrm{CO}_{2 \text {-soill }}, \mathrm{CO}_{2 \text {-flux }}, \mathrm{N}_{2} \mathrm{O}_{\text {-soil }}, \mathrm{N}_{2} \mathrm{O}_{\text {-flux }}$, and other soil properties were calculated using PROC CORR with Bonferroni corrections. Stepwise regressions (PROC STEPWISE, SAS Institute 2013) were performed using bidirectional elimination following pre-selection with main component analyses. 


\section{RESULTS AND DISCUSSION}

\section{Carbon dynamics}

Total soil carbon $\left(\mathrm{C}_{\text {Total }}\right)$ averaged about $30 \mathrm{~g} \mathrm{~kg}^{-1}$ across the site, varying from $9.4 \mathrm{~g} \mathrm{~kg}^{-1}$ to $50.9 \mathrm{~g} \mathrm{~kg}^{-}$ ${ }^{1}$ near the soil surface, and from 12.6 to $93.9 \mathrm{~g} \mathrm{~kg}^{-1}$ at depth (Table 1). Respective coefficients of variation $(\mathrm{CV})$ were $\geq 28 \%$. $\mathrm{C}_{\text {Total }}$ and its variability was consistent with values reported for agricultural soils in the region (Bambrick et al., 2010; Peichl et al., 2006; Rivest et al., 2013). System, depth and distance from trees did not significantly influence $\mathrm{C}_{\text {Total }}$. Soil heterogeneity, redistribution of leaves by the wind, and burial of branches likely explained the relatively high degree of spatial variability across the plots. This high variability may explain the lack of significant effects.

In 2013, soluble carbon $\left(\mathrm{C}_{\text {soluble }}\right)$ concentrations averaged $266 \mathrm{mg} \mathrm{kg}^{-1}$ at $0.125 \mathrm{~m}$ and $241 \mathrm{mg} \mathrm{kg}^{-1}$ at $0.250 \mathrm{~m}$ (Table 1), with a CV $(29 \%)$ in the same range as for $\mathrm{C}_{\text {Total }}$. Neither depth nor distance from

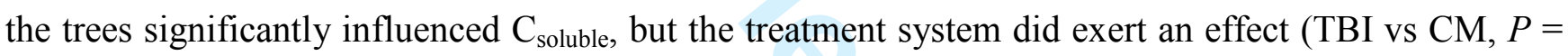
0.001). The range of soluble $\mathrm{C}$ values (115 to $357 \mathrm{mg} \mathrm{kg}^{-1}$ ) in $\mathrm{CM}$ was wider and higher than that of TBI (128 to $273 \mathrm{mg} \mathrm{kg}^{-1}$ ), although mean soil $\mathrm{C}_{\text {soluble }}$ was higher in TBI compared to CM. Given that the same crop was planted in both systems, this difference could have been attributed to faster release of $\mathrm{C}_{\text {soluble }}$ from leaf litter.

Soil $\mathrm{CO}_{2}$ concentrations $\left(\mathrm{CO}_{2 \text {-soil }}\right)$ ranged from 636 to $47149 \square \mathrm{g} \mathrm{L}^{-1}$, with $\mathrm{CVs}$ of about $47 \%$ (Table 1). These values were comparable to those estimated in conventional agricultural studies for similar climates (Allaire et al., 2012, 2015), and in agroforestry systems (Peichl et al., 2010). $\mathrm{CO}_{2 \text {-soil }}$ was consistently $(\mathrm{P}<0.0001)$ lower $+10 \mathrm{~m}$ (East) than $-10 \mathrm{~m}$ (West) from the tree row (Fig. 2), even though the same hybrid poplars were planted on either side of the plots. This difference may be related to natural soil gradients across the site (among them slope, large gradient in soil texture, horizonation and $\mathrm{pH})$. 
Despite potential field gradients, the presence of trees (TBI vs $\mathrm{CM}, \mathrm{P}=0.001$ ), the distance from them $(\mathrm{P}<0.0001)$, the soil depth $(\mathrm{P}<0.0001)$ and seasonal variation $(\mathrm{P}<0.0001)$ strongly affected

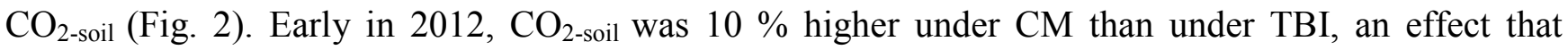
disappeared toward the end of the growing season. The difference may be attributed to the trees, which affected soil temperature and moisture content (correlated with $\mathrm{CO}_{2 \text {-soil }}$ at $\mathrm{P}<0.0001$ ), that control $\mathrm{CO}_{2}$ production in the soil (Allaire et al., 2012, 2015). Microbial processes are more efficient in using soil C (lower $\mathrm{CO}_{2}$ emissions) in TBI than in $\mathrm{CM}$ systems, possibly because the microbial communities are more diverse (Lacombe et al., 2009; Rivest et al., 2013). In contrast, the agricultural system did not influence $\mathrm{CO}_{2 \text {-soil }}$ over the 2013 growing season $(\mathrm{P}=0.22)$, probably because deep tillage severed tree roots and redistributed organic residues from pruning, increasing spatial variability and temporarily offsetting the effects that trees would exert on soil properties.

Within TBI, $\mathrm{CO}_{2 \text {-soil }}$ rose by $20 \%$ as the distance from the trees increased (Fig. 2, +4 and $-4 \mathrm{~m}$ ) with the highest concentration under the annual crop located in the middle of the alley. This trend was consistent from season to season, and likely related to intensive soil microbial and root activity of the annual crop (forage and grass). Changes in soil temperature and moisture also likely drove this trend. Both properties varied systematically with the distance from the trees $(P<0.0001)$ and were correlated with $\mathrm{CO}_{2 \text {-soil }}(P<0.0001)$, since higher soil temperature was favoured under forage and grass than around trees. Soil water content within the topmost $30 \mathrm{~cm}$ was higher under crops than under trees.

As expected, $\mathrm{CO}_{2 \text {-soil }}$ varied over the growing season $(P=0.001)$, but was only influenced by the

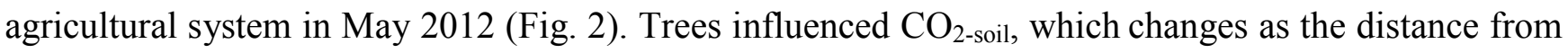
them increases, but the average over the whole site did not. Less snow accumulates around the trees during winter, and soil temperature remained higher beneath and around trees prior to leaf out. In dryer years, little snow accumulated over the site, as was the case in 2013, which diminished the aforementioned springtime difference. 
Since the trees influenced $\mathrm{CO}_{2}$-soil, litter fall deposit, and the soil water regimen at different depths $(\mathrm{P}=0.0001)$, we expected that they would affect $\mathrm{CO}_{2 \text {-soil }}$ differently at various soil depths. Neither agricultural system nor distance from the trees interacted with depth on $\mathrm{CO}_{2 \text {-soil, }}$ probably because the pronounced gradient of increasing $\mathrm{CO}_{2}$ concentrations with depth masked the effects of all other

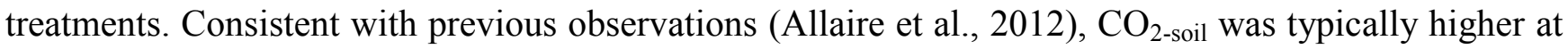
$0.25 \mathrm{~m}$ depth $\left(\right.$ mean $\left.=14339 \mu \mathrm{g} \mathrm{L}^{-1}\right)$ compared with $0.125 \mathrm{~m}$ depth $\left(\right.$ mean $=9565 \mu \mathrm{g} \mathrm{L}{ }^{-1}$, Table 1$)$. The $40 \%$ concentration difference was maintained between depths throughout 2012. In 2013, the difference was smaller, decreasing toward the end of the growing season (time $\mathrm{x}$ depth interaction: $\mathrm{P}=0.008$ ). The soil was drier in 2013, which induced greater $\mathrm{CO}_{2}$ exchange with the atmosphere, resulting in lower concentrations at depth than in 2012. No significant interaction of depth with trees could be attributed to root systems that were distributed more deeply than the measurements $(0-0.3 \mathrm{~m}$ depth).

Average $\mathrm{CO}_{2}$ flux $\left(\mathrm{CO}_{2 \text {-flux }}\right)$ across the site was $110 \mu \mathrm{g} \mathrm{m}^{-2} \mathrm{~s}^{-1}$ in 2012 and $101 \mu \mathrm{g} \mathrm{m}^{-2} \mathrm{~s}^{-1}$ in 2013 (Table 1). Seasonal and inter-annual $\mathrm{CO}_{2 \text {-flux }}$ ranged from over two orders of magnitude (7.9-661 $\mu \mathrm{g} \mathrm{\textrm {m } ^ { - }}$ ${ }^{2} \mathrm{~s}^{-1}$ ), so that CVs were as high as $94 \%$ (Table 1 ). The fluxes were comparable to estimates (5.1-312 $\mu \mathrm{g}$ $\mathrm{m}^{-2} \mathrm{~s}^{-1}$ ) from other conventional agricultural cropping systems in similar climates (Fang et al. 1998; Allaire et al., 2008, 2012), but variations in CM fluxes were slightly higher (i.e., CVs > $100 \%$ ). Other TBI systems incorporating hybrid poplars have reported a narrower range of $\mathrm{CO}_{2}$ fluxes $\left(83-222 \mu \mathrm{g} \mathrm{m}^{-2}\right.$ $\mathrm{s}^{-1}$; Peichl et al., 2006).

The high degree of variability in surface $\mathrm{CO}_{2}$ emissions depended, in part, upon agricultural system (TBI vs $\mathrm{CM}, \mathrm{P}=0.09$ ), but weakly so. In contrast, surface emission variability strongly influenced by the distance from the trees $(\mathrm{P}=0.0003)$. Indeed, $\mathrm{CO}_{2 \text {-flux }}$ was up to $20 \%$ higher under $\mathrm{CM}$ than under TBI in 2012, given that carbon turnover is typically higher under monoculture. On the St-Paulin site,

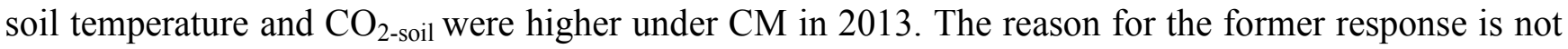


clear, but it may be due to the deep tillage that had redistributed soil $\mathrm{C}$, resulting in greater food availability for soil organisms all across the field and increase in variability.

Distance from the trees significantly influenced $\mathrm{CO}_{2 \text {-flux }}$ but only in $2013(\mathrm{P}=0.0003)$. Variation within the same treatment was greater in 2012 than in 2013, even though the overall variability across the site during summer 2013 was higher (Table 1, Fig. 3). Although the response was not significant in 2012, more $\mathrm{CO}_{2}$ was emitted at a distance of $4 \mathrm{~m}$ from the central tree row in $2013(0 \mathrm{~m})$, i.e., within the crop alley where trees exerted the least influence (Fig. 3). The tree row-alley difference was more noticeable in May and June, which would explain the significant time $\mathrm{x}$ treatment interaction $(\mathrm{P}=0.002)$.

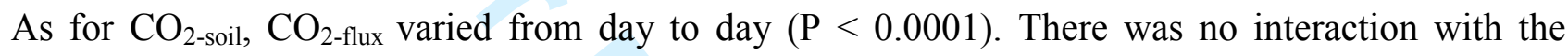
agricultural system in 2012, since the trend for higher fluxes under CM was maintained over the entire summer. However, the agricultural system interacted with time in 2013 . TBI tended to emit more $\mathrm{CO}_{2}$ than CM during the hottest periods and less during the coldest periods. When moisture was insufficient, such as in 2013, a reversal of the effects that trees had exerted on $\mathrm{CO}_{2}$ emissions began when drawndown soil moisture exceeded evapotranspirative demand, allowing soil temperature to rise, and gas diffusion and $\mathrm{CO}_{2}$ emissions to increase. Higher emissions occurred in May and June (Fig. 3), nearly one month earlier than usually observed in Quebec (Allaire et al., 2008, 2012, 2015), most likely because of earlier spring onset, a thinner snow cover in 2012 (Fig. 2) and new available C released by deep tillage. Negative fluxes were sporadically measured. These responses mainly occurred under cold soil conditions during fall, as observed in other studies under cold conditions (Allaire et al., 2008, 2015).

Trees not only directly affected carbon emissions and soil $\mathrm{C}$ pools, but also exerted indirect effects through soil physico-chemical properties. For example, $\mathrm{CO}_{2 \text {-soil }}$ concentrations at 0.125 and $0.250 \mathrm{~m}$ depths were strongly inter-correlated $(\mathrm{r}=0.85)$, while they were weakly correlated with the 
resulting surface $\mathrm{CO}_{2-\text { flux }}(\mathrm{r}=0.25) . \mathrm{C}_{\text {Total }}$ and $\mathrm{C}_{\text {soluble }}$ pools accounted for $1-2 \%$ of the variation in $\mathrm{CO}_{2-}$ soil, while soil temperature and moisture accounted for at least $40 \%$. These two physical parameters drive soil microbial activities that result in $\mathrm{CO}_{2}$ production (Fang and Moncrieff, 2001). Microbial and root activity increases as temperature rises, as does $\mathrm{CO}_{2}$ production, when temperature, moisture and oxygen levels remain within physiological tolerable limits (Smith et al., 2003; Rivest et al., 2013). Increases in soil $\square_{\mathrm{v}}$ and temperature near the surface tended to increase $\mathrm{CO}_{2 \text {-soil. }}$ Bulk density and $\mathrm{K}_{\text {sat }}$

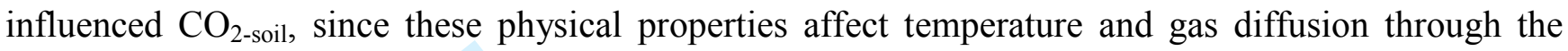
control over the moisture content. Chemical properties, such as nitrate concentration and $\mathrm{pH}$, were also closely correlated with $\mathrm{CO}_{2 \text {-soil }}$ through their effects on microbial activities; carbon and nitrogen are necessary to meet microbial metabolic demands, while $\mathrm{pH}$ influences $\mathrm{C}$ and $\mathrm{N}$ availability (Bezdicek et al., 2003). Consequently, $\mathrm{CO}_{2 \text {-soil }}$ was explained by $\mathrm{N}_{2} \mathrm{O}_{\text {-soil }}$ and nitrate concentrations. Overall, physico-chemical soil properties accounted for up to $78 \%$ of the total variation in $\mathrm{CO}_{2 \text {-soil. }}$.

About $34 \%$ of the variation in $\mathrm{CO}_{2 \text {-flux }}$ could be explained by soil temperature, sand content, and $\mathrm{CO}_{2 \text {-soil. }}$ As described earlier and also explained in several gas flux studies (Allaire et al., 2008, 2012,

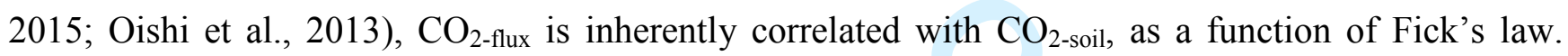
Since $\mathrm{N}$ cycling influences microbial activity (Thornton et al., 2007), $\mathrm{N}_{2} \mathrm{O}_{\text {-soil }}$ was negatively correlated with $\mathrm{CO}_{2 \text {-flux }}(\mathrm{r}=-0.376,0.125 \mathrm{~m} ; \mathrm{r}=-0.397,0.25 \mathrm{~m})$. These properties were all significantly influenced by the agricultural system and the presence of trees $(\mathrm{P}<0.01)$.

TBI tended to have $\mathrm{C}_{\text {Total }}$ equal to that of $\mathrm{CM}$, higher soil $\mathrm{C}_{\text {soluble, lower }} \mathrm{CO}_{2 \text {-soil }}$ and $\mathrm{CO}_{2 \text {-flux }}$ than CM. These results highlight the environmental benefits of TBI on GHG emissions, even under organic production, together with the carbon stored in wood, which is discussed in another study (Alam et al., 2014; Kinans et al., 2014, 2015).

\section{Nitrogen dynamics}


Soil $\mathrm{NO}_{3}^{-}$ranged from 1 to $47 \mathrm{mg} \mathrm{kg}^{-1}$ (Table 1 ), while $\mathrm{NO}_{2}^{-}$was routinely below detection limits. Their combined concentrations were lower than those typically reported for conventional agricultural systems (Pennock et al., 1992; Clemens et al., 1999); and could be attributed to very low (organic) fertilization rates of the system compared to conventional applications of inorganic-N fertilizer. CVs of both anions ranged from about 60 to $75 \%$, which were similar to those estimated under TBI production in other studies (Beaudette et al., 2010; Evers et al., 2010).

$\mathrm{NO}_{3}{ }^{-}$and $\mathrm{NO}_{2}{ }^{-}$were not influenced by agricultural system (TBI vs CM) in this study, but they were influenced by the distance from trees. The presence of leaf litter may explain the effect of trees on $\mathrm{NO}_{3}{ }^{-}$ . Leaf litter is a source of complex $\mathrm{N}$, which in turn may affect bacterial and fungi activity. Higher nitrate may be due to tree effects on soil moisture, particularly during springtime (tree distance, $P=$ 0.08). Yet, the distance from the trees did not influence $\mathrm{NO}_{2}^{-}$, when concentrations were detectable. Nitrite is an ephemeral compound and can be lost from soils through chemo-denitrification (as NO) and several other processes (Conrad, 1994). Correlations involving the two $\mathrm{N}$ species were harder to establish, as the amount of data was limited because they were measured only once during the entire experiment.

As generally observed in other GHG studies (Skinner et al., 2014), $\mathrm{N}_{2} \mathrm{O}_{\text {-soil }}$ was three orders of magnitude lower than $\mathrm{CO}_{2 \text {-soil }}$ (Table 1). Mean $\mathrm{N}_{2} \mathrm{O}_{\text {-soil }}$ was about $2.4 \mu \mathrm{g} \mathrm{L}^{-1}$ (minimum, $0.32 \mu \mathrm{g} \mathrm{L}^{-1}$; maximum, $25.2 \mu \mathrm{g} \mathrm{L}^{-1}$; Table 1), which corresponds to lower values encountered for wheat-maize

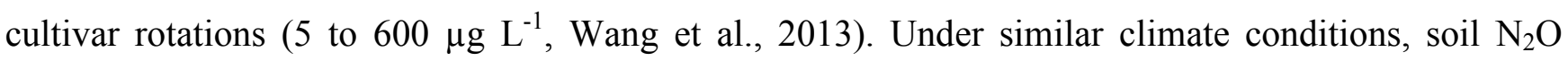
ranges from 285 to $563 \mu \mathrm{g} \mathrm{L}^{-1}$ in forestry systems (Lavoie et al., 2013). Low concentrations and emissions of nitrous oxide were associated with low fertilizer and $\mathrm{N}$ inputs in the system. $\mathrm{N}_{2} \mathrm{O}$ was always detected at both soil depths, but its values were highly variable (CVs up to 100\%). This level of variability is frequently observed for $\mathrm{N}_{2} \mathrm{O}$ in agricultural fields (Clemens et al., 1999; Desjardins et al., 2010; Skinner et al., 2014). 
Agricultural system (system $\mathrm{x}$ time interaction, $P=0.008)$, together with distance from trees $(P=$ 0.002), influenced $\mathrm{N}_{2} \mathrm{O}_{\text {-soil. }}$ TBI formed slightly more soil $\mathrm{N}_{2} \mathrm{O}$ than the $\mathrm{CM}$ system early in the season (Fig. 4). Otherwise, similar seasonal, spatial, and depth trends were observed for $\mathrm{N}_{2} \mathrm{O}_{\text {-soil }}$ and $\mathrm{N}_{2} \mathrm{O}_{\text {-Flux }}$. Higher emissions during spring were likely associated with leaf litter decay and release of organic and inorganic nitrogen, which is transported into the profile with snowmelt; this $\mathrm{N}$ input was not available in plots without trees. Otherwise, $\mathrm{N}$ inputs were very limited and similar among plots, resulting in similar $\mathrm{N}_{2} \mathrm{O}$ dynamics between systems. Most $\mathrm{N}_{2} \mathrm{O}$ that is formed within the uppermost $5 \mathrm{~cm}$ of soil (Tenuta and Sparling, 2011) is rapidly consumed by other microorganisms within the same layer (Wagner-Riddle et al., 2008); consequently, surface fluxes that we measured were low or frequently below detection limits (data not shown). Further, $\mathrm{N}_{2} \mathrm{O}$ could only be consistently detected and measured at $0.15 \mathrm{~m}$ and $0.25 \mathrm{~m}$ depths. Differences in measurement depths and the low number of useful measurement events were among the variety of factors that affect $\mathrm{N}_{2} \mathrm{O}$ formation and consumption and which made analysis and interpretation of treatment responses difficult.

Greater $\mathrm{N}_{2} \mathrm{O}_{\text {-soil }}$ concentrations were observed at the beginning and end of the growing season (Fig.

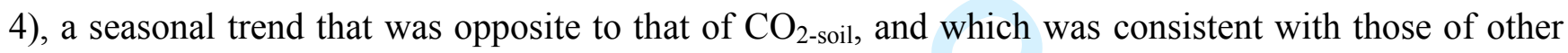
studies (Desjardins et al., 2010). One main reason for higher $\mathrm{N}_{2} \mathrm{O}$ concentrations during springtime was likely due to the activities of specific groups of bacterial $\mathrm{N}_{2} \mathrm{O}$ producers. These bacteria tend to be more active under cold soil conditions (Wagner-Riddle et al., 2008). The CV that was associated with mean $\mathrm{N}_{2} \mathrm{O}_{\text {-flux }}$ reached a value of $1693 \%$ during the growing season (Table 1). This strong variability and range of values has also been observed in most studies (Clemens et al., 1999), and likely results from the complex nature of soil $\mathrm{N}_{2} \mathrm{O}$ formation and emissions.

Although highly variable, temperature and moisture explained more than $55 \%$ of variability in $\mathrm{N}_{2} \mathrm{O}$. soil, consistent with other studies (Lellei-Kovács et al., 2011). Nitrate, BD, and pH explained an additional $6 \%$ of the variation. $\mathrm{N}_{2} \mathrm{O}_{\text {-soil }}$ increased with $\mathrm{NO}_{3}{ }^{-}$concentrations, since the latter is the 
essential precursor for the denitrification process. Since the soil is relatively acidic, increased $\mathrm{pH}$ also favoured higher $\mathrm{N}_{2} \mathrm{O}_{\text {-soil, }}$, probably because more nutrients became available and soil conditions were more conducive to nitrification (Bouwman et al., 2002). $\mathrm{N}_{2} \mathrm{O}_{\text {-soil }}$ decreased with increasing BD -probably because of limited diffusion and oxygen import in the soil; greater anoxia taking available $\mathrm{NO}_{3}{ }^{-}$to $\mathrm{N}_{2}$. Soil $\mathrm{WC}, \mathrm{C}_{\text {Total }}$ and clay content explained another $7 \%$ of the variation in $\mathrm{N}_{2} \mathrm{O}_{\text {-flux }}$, which agrees with Clemens et al. (1999). Clay content influenced $\mathrm{N}_{2} \mathrm{O}$ formation by affecting the soil moisture regime, while soil carbon $\left(\mathrm{C}_{\text {Total }}\right)$ may interfere with $\mathrm{N}_{2} \mathrm{O}$ formation (Paré and BedardHaughn, 2012). All of these parameters, except for clay content, were significantly influenced by the presence of trees.

\section{CONCLUSION}

Under organic production with few external inputs, we expected a small but significant effect of trees on carbon and nitrogen dynamics in soil. Although trees influenced most soil physico-chemical properties, their presence result in very small changes in $\mathrm{C}_{\text {Total }}, \mathrm{N}_{2} \mathrm{O}_{\text {-soil }}$ and $\mathrm{N}_{2} \mathrm{O}_{\text {-flux }}$. Trees had stronger

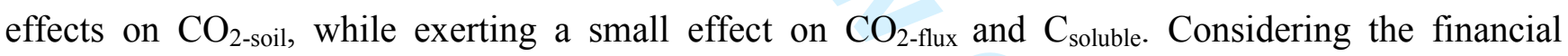
savings relative to applying fertilizers, working the soil, preparing the seed bed, tree harvesting for short and long rotation and so on, considering that TBI tends to reduce emissions of these gases relative to $\mathrm{CM}$ and other environmental advantages, such as $\mathrm{C}$ sequestration in wood, not discussed here, therefore, installation of TBI systems with low input in this climate and under current land management practices could be a favourable means of applying a GHG mitigation strategy.

\section{ACKNOWLEDGEMENTS}

We acknowledge the financial support of the Agricultural Greenhouse Gases Program (AGGP) of Agriculture and Agri-Food Canada. We thank the undergraduate students (particularly Antoine Vallet), and research teams from Université Laval (Soil Hydrodynamics Group), Université de Sherbrooke, 
Université de Montréal and Université du Québec en Outaouais (UQO) for their collaboration and assistance with field measurements. We express our gratitude to Daniel Marcotte for training several people on the instruments that were used in the study. Finally, we are particularly grateful to Le Baluchon Eco-Resort (St-Paulin) for allowing access to their land.

\section{REFERENCES}

Akaike, H. 1974. A new look at the statistical model identification. IEEE Trans. Autom. Control 19: 716-723.

Alam, M., Olivier, A., Paquette, A., Dupras, J., Revéret, J.-P., Messier, C. 2014. A general framework for the qualification and evaluation of ecosystem services of tree-based intercropping systems. Agrofor. Syst. 88 : 679-691.

Allaire, S.E., Baril, B., Vanasse, A., Lange, S.F., MacKay, J., Smith, D.L. 2015. Carbon dynamics in a biochar-amended loamy soil under switchgrass. Can. J. Soil Sci. 95 : 113-118.

Allaire, S.E., Lange, S.F., Lafond, J.A., Pelletier, B., Cambouris, A.N., Dutilleul, P. 2012. Multiscale spatial variability of $\mathrm{CO}_{2}$ emissions and correlations with physico-chemical soil properties. Geoderma 170: 251-260.

Allaire, S.E., Dufour-L'Arrivée, C., Lafond, J.A., Lalancette, R., Brodeur, J. 2008. Carbon dioxide emissions by urban turfgrass areas. Can. J. Soil Sci. 88: 529-532. 
Bambrick, A.D., Whalen, J.K., Bradley, R.L., Cogliastro, A., Gordon, A.M., Olivier, A., Thevathasan, N.V. 2010. Spatial heterogeneity of soil organic carbon in tree-based intercropping systems in Quebec and Ontario, Canada. Agrofor. Syst. 79: 343-353.

Bartlett, R.J., Ross, D.S. 1988. Colorimetric determination of oxidizable carbon in acid soil solutions. Soil Sci. Soc. Am. J. 52: 1191-1192.

Beaudette, C., Bradley, R.L., Whalen, J.K., McVetty, P.B.E., Vessey, K., Smith, D.L. 2010. Tree-based intercropping does not compromise canola (Brassica napus L.) seed oil yield and reduces soil nitrous oxide emissions. Agric. Ecosyst. Environ. 139: 33-39.

Bezdicek, D.F., Beaver, T., Granatstein, D. 2003. Subsoil ridge tillage and lime effects on soil microbial activity, soil $\mathrm{pH}$, erosion, and wheat and pea yield in the Pacific Northwest, USA. Soil Tillage Res. 74: 55-63.

Blake, G.R., and K.H. Hartge. 1986. Bulk density. p. 363-375. In Klute, A. 1986 Methods of soil analysis. Part 1. Physical and mineralogical methods. $2^{\text {nd }}$ ed. American Society of Agronomy, Inc, Soil Science Society of America, Inc, Madison, WI. USA.

Bouwman, A.F., Boumans, L.J.M., Batjes, N.H. 2002. Emissions of $\mathrm{N}_{2} \mathrm{O}$ and NO from fertilized fields: Summary of available measurement data. Global Biogeochem. Cy. 16: art. no. 1058. doi: http://10.1029/2001GB001811.

Box, G.E.P, Cox, D.R. 1964. An analysis of transformations. J. R. Stat. Soc. Series B Stat. Methodol. 26: 211-252.

Clemens, J., Schillinger, M.P., Goldbach, H., Huwe B. 1999. Spatial variability of $\mathrm{N}_{2} \mathrm{O}$ emissions and soil parameters of an arable silt loam - A field study. Biol. Fertil. Soils 28: 403-406. 
Conrad, R. 1994. Compensation concentration as critical value for regulating the flux of trace gases between soil and atmosphere. Biogeochem. 27: 155-170.

Davis, J.E., Norman, J.M. 1988. Effects of shelter on plant water use. Agric. Ecosyst. Environ. 22: 393402.

Desjardins, R.L., Pattey, E., Smith, W.N., Worth, D., Grant, B., Srinivasan, R., MacPherson, J.I., Mauder, M. 2010. Multiscale estimates of $\mathrm{N}_{2} \mathrm{O}$ emissions from agricultural lands. Agric. For. Meteorol. 150: 817-824.

Dixon, R.K., Winjum, J.K., Andrasko, K.J., Lee, J.J., Schroeder, P.E. 1994. Integrated land-use systems: Assessment of promising agroforest and alternative land-use practices to enhance carbon conservation and sequestration. Climatic Change 27: 71-92.

Environment Canada. 2013. Services de données - Données climatologiques. Environnement Canada. http://climat.meteo.gc.ca/ (Consulted on Januray 2015).

Evers, A.K., Bambrick, A., Lacombe, S., Dougherty, M.C., Peichl, M., Gordon, A.M., Thevathasan, N.V., Whalen, J.K., Bradley, R.L. 2010. Potential greenhouse gas mitigation through temperate tree-based intercropping systems. Open Agric. J. 4: 49-57.

Fang, C., Moncrieff, J.B. 2001. The dependence of soil $\mathrm{CO}_{2}$ efflux on temperature. Soil Biol. Biochem. 33: $155-165$.

Fang, C., Moncrieff, J.B., Gholz, H.L., Clark, K.L. 1998. Soil $\mathrm{CO}_{2}$ efflux and its spatial variation in a Florida slash pine plantation. Plant Soil 205: 135-146.

Jordan, C.F. 2004. Organic farming and agroforestry: Alleycropping for mulch production for organic farms of South eastern United States. Agrofor. Syst. 61: 79-90. 
Keeney, D.R., and Nelson, D.W. 1982. Chap 33: Nitrogen - Inorganic Forms Page, Pages 643-698 in A.L., Miller, R.H. and Keeney, D.R. Methods of Soil Analysis. Part 2. Chemical and Microbiological Properties, $2^{\text {nd }}$ ed. Soil Science Society of America, Madison, WI. USA.

Klute, A., Dirksen C. 1986. Hydraulic conductivity and diffusivity: Laboratory methods. p 687-734 In Klute, A. 1986 Methods of soil analysis. Part 1. Physical and mineralogical methods. $2^{\text {nd }}$ ed. American Society of Agronomy, Inc, Soil Science Society of America, Inc, Madison, WI. USA.

Lacombe, S., Bradley, R.L., Hamel, C., Beaulieu, C. 2009. Do tree-based intercropping systems increase the diversity and stability of soil microbial communities? Agric. Ecosys. Environ. 131: 25-31.

Lamontagne, L., Nolin, M.C. 1997. Dossier des noms de sols du Québec 1997 : SISCan (Système d'information des sols au Canada). Agriculture et Agroalimentaire Canada, Direction générale de la recherche, Sainte-Foy. Qc. 65 p.

Lange, S.F., Allaire, S.E., van Bochove, E. 2008. Transfer of $\mathrm{CO}_{2}, \mathrm{~N}_{2} \mathrm{O}$ and $\mathrm{CH}_{4}$ to butyl rubber (polyisobutylene) septa during storage. J. Environ. Monit. 10 : 775-777. doi: http://10.1039/b719729b.

Lavoie, M., Kellman, L., Risk, D. 2013. The effects of clear-cutting on soil $\mathrm{CO}_{2}, \mathrm{CH}_{4}$, and $\mathrm{N}_{2} \mathrm{O}$ flux, storage and concentration in two Atlantic temperate forests in Nova Scotia, Canada. Forest Eco. Manag. 304: 355-369.

Lellei-Kovács, E., Kovács-Láng, E., Botta-Dukát, Z., Kalapos, T., Emmett, B., Beier, C. 2011. Thresholds and interactive effects of soil moisture on the temperature response of soil respiration. Europ. J. Soil Biol. 47 : 247-255.

Lorenz, K., Lal, R. 2014. Soil organic carbon sequestration in agroforestry systems. A review. Agron. Sustain. Dev. 34 : 443-454. doi:http://10.1007/s13593-014-0212-y. 
Montagnini, F., Nair, P.K.R. 2004. Carbon sequestration: An underexploited environmental benefit of agroforestry systems. Agrofor. Syst. 61: 281-295.

Mungai, N.W., Motavalli, P.P. 2006. Litter quality effects on soil carbon and nitrogen dynamics in temperate alley cropping systems. Ap. Soil Ecol. 31: 32-42.

Nair, P.K.R. 2012. Carbon sequestration studies in agroforestry systems: a reality-check. Agrofor. Syst. 86: $243-253$.

Oelbermann, M., Voroney, R.P., Gordon, A.M. 2004. Carbon sequestration in tropical and temperate agroforestry systems: a review with examples from Costa Rica and southern Canada. Agric. Ecosyst. Environ. 104: 359-377.

Oishi, A.C., Palmroth, S., Butnor, J.R., Johnsen, K.H., Oren, R. 2013. Spatial and temporal variability of soil $\mathrm{CO}_{2}$ efflux in three proximate temperate forest ecosystems. Agr. Forest Meteorol. 171: 256269.

Paré, M.C., Bedard-Haughn, A. 2012. Soil organic matter quality influences mineralization and GHG emissions in cryosols: a field-based study of sub- to high Arctic. Glob. Change Biol. 19: 11261140. doi:http://10.1111/gcb.12125.

Peichl, M., Arain, M.A., Ullah, S., Moore, T.R. 2010. Carbon dioxide, methane, and nitrous oxide exchanges in an age-sequence of temperate pine forests. Global Change Biol. 16: 2198-2212.

Peichl, M., Thevathasan, N.V., Gordon, A.M., Huss, J., Abohassan, R.A. 2006. Carbon sequestration potentials in temperate tree-based intercropping systems, southern Ontario, Canada. Agrofor. Syst. 66: $243-257$. 
Pennock, D.J., van Kessel, C., Farrell, R.E., Sutherland, R.A. 1992. Landscape-scale variations in denitrification. Soil Sci. Soc. Am. J. 56: 770-776.

Quinkenstein, A., Wöllecke, J., Böhm, C., Grünewald, H., Freese, D., Schneider, B.U., Hüttl, R.F. 2009. Ecological benefits of the alley cropping agroforestry system in sensitive regions of Europe. Environ. Sci. Policy 12: 1112-1121.

Rivest, D., Lorente, M., Olivier, A., Messier, C. 2013. Soil biochemical properties and microbial resilience in agroforestry systems: Effects on wheat growth under controlled drought and flooding conditions. Sci. Total Environ. 463: 51-60.

Rochette, P., McGinn, S.M. 2005. Methods for measuring soil-surface gas fluxes. Pages $465-502$ in Alvarez-Benedi, J., Munoz-Carpeno, R., eds. Handbook of Applied Techniques for Characterizing Processes in the Soil Environment. CRC Press, Boca Raton, FL.

Rousseau, A.N., Hallema, D.W., Gumiere, S.J., Carrer, G., Fossey, M. 2012. Progress report project PACC-26 - The influence of alley cropping systems on soil water dynamics and soil erosion in a changing climate. INRS Report R-1334. March $8^{\text {th }}$, 2012, Quebec, Canada.

SAS Institute. 2013. SAS user guide: Statistics.Version 9.3. SAS Institute Inc., Cary, NC, USA.

Schoeneberger, M., Bentrup, G., de Gooijer, H., Soolanayakanahally, R., Sauer, T., Brandle, J., Zhou, X., Curren, D. 2012. Branching out: Agroforestry as a climate change and adaptation tool for agriculture. J. Soil Water Conserv. 67: 128A-136A.

Schroeder, P. 1993. Agroforestry systems: integrated land use to store and conserve carbon. Clim. Res. 3: $53-60$. 
Skinner, C., Gattinger, A., Muller, A., Mäder, P., Fließbach, A., Stolze, M., Ruser, R., Niggli, U. 2014. Greenhouse gas fluxes from agricultural soils under organic and non-organic management - A global meta-analysis. Sci. Total Environ. 468: 553-563.

Skjemstad, J.O., Baldock, J.A. 2007. Total and organic carbon. Pages 223-237 in Carter, M.R., Gregorich, E.G., eds. Soil Sampling and Methods of Analysis, $2^{\text {nd }}$ ed. CRC Press, Boca Raton, FL.

Smith, K.A., Ball, T., Conen, F., Dobbie, K.E., Massheder, J., Rey, A. 2003. Exchange of greenhouse gases between soil and atmosphere: Interactions of soil physical factors and biological processes. Eur. J. Soil Sci. 54: 779-791.

Tenuta, M., Sparling, B. 2011. A laboratory study of soil conditions affecting emissions of nitrous oxide from packed cores subjected to freezing and thawing. Can. J. Soil Sci. 91: 223-233.

Thevathasan, N.V., Gordon, A.M., Bradley, R., Cogliastro, A., Folkard, P., Grant, R., Kort, J., Liggins, L., Njenga, F., Olivier, A., Pharo, C., Powell, G., Rivest, D., Schiks, T., Trotter, D., Rees, K., Whalen, J., Zabek, L. 2012. Agroforestry research and development in Canada: The way forward. Pages 247-283 in Nair, P.K.R., Garrity, D., eds. Agroforestry - The Future of Global Land Use. Advances in Agroforestry, V. 9. Springer, Netherlands.

Thornton, P.E., Lamarque, J.F. , Rosenbloom, N.A., Mahowald, N.M. 2007. Influence of carbon nitrogen cycle coupling on land model response to $\mathrm{CO}_{2}$ fertilization and climate variability. Global Biogeochem. Cy. 21: 1-9. doi: http://10.1029/2006GB002868.

Topp, G.C., Davis, J.L., Annan, A.P. 1980. Electromagnetic determination of soil water content: Measurements in coaxial transmission lines. Water Resour. Res. 16: 574-582.

Udawatta, R.; Jose, S. 2012. Agroforestry Strategies to Sequester Carbon in Temperate North America. Agroforest. Syst. 86: 225-0242. 
Wagner-Riddle, C., Hu, Q.C., van Bochove, E., Jayasundara, S. 2008. Linking nitrous oxide flux during spring thaw to nitrate denitrification in the soil profile. Soil Sci. Soc. Am. J. 72: 908-916.

Wang, Y.Y., Hu, C.S., Ming, H., Zhang, Y.M., Li, X.X., Dong, W.X., Oenema, O. 2013. Concentration profiles of $\mathrm{CH}_{4}, \mathrm{CO}_{2}$ and $\mathrm{N}_{2} \mathrm{O}$ in soils of a wheat-maize rotation ecosystem in North China Plain, measured weekly over a whole year. Agric. Ecosyst. Environ. 164: 260-272.

Wang, Z., Grant, R.F., Arain, A., Bernier, P., Chen, B., Chen, J., Coops, N., Govind, A., Guindon, L., Hember, R., Kurz, W.A., Peng, C., Price, D.T., Stinson, G., Sun, J., Trofymow, J.A. and Yeluripati, J. 2011. Model intercomparison to evaluate climate and disturbance effects on interannual variation in net ecosystem productivity of a coastal temperate forest landscape. Ecol. Model. 222: 3236- 3249.

Winans, K., Whalen, J.K., Cogliastro, A., Rivest, D., Ribaudo, L. 2014. Soil carbon stocks in two hybrid poplar-hay crop systems in southern Quebec, Canada. Forests 5: 1952-1966. doi: http://10.3390/f5081952.

Yang, J.Y., Huffman, E.C., Drury, C.F., Yang, X.M., De Jong, R. 2011. Estimating the impact of manure nitrogen losses on total nitrogen application on agricultural in Canada. Can. J. Soil Sci. 91: 107-122. 
Table 1. Descriptive statistics of C- and N-related parameters.

\begin{tabular}{|c|c|c|c|c|c|c|c|c|}
\hline Property & Units & Year & Depth (m) & $\mathrm{n}$ & Mean $^{b}$ & Min & Max & $\mathrm{CV}(\%)$ \\
\hline \multirow[t]{2}{*}{${ }^{\mathrm{a}} \mathrm{C}_{\text {Total }}$} & $\left(\mathrm{g} \mathrm{g}^{-1}\right)^{*} 100$ & 2013 & 0.125 & 29 & 2.86 & 0.94 & 5.09 & 28.7 \\
\hline & & 2013 & 0.250 & 30 & 3.42 & 1.26 & 9.39 & 47.1 \\
\hline \multirow[t]{2}{*}{${ }^{\mathrm{a}} \mathrm{C}_{\text {Soluble }}$} & $\mathrm{mg} \mathrm{kg}^{-1}$ & 2013 & 0.125 & 30 & 266 & 152 & 466 & 30.0 \\
\hline & & 2013 & 0.250 & 29 & 241 & 115 & 382 & 29.4 \\
\hline \multirow[t]{4}{*}{$\mathrm{CO}_{2 \text {-soil }}$} & $\mu \mathrm{g} \mathrm{L}_{\text {soil air }}^{-1}$ & 2012 & 0.125 & 179 & $9.6 \mathrm{E} 3$ & 636 & $3.0 \mathrm{E} 4$ & 49.6 \\
\hline & & 2012 & 0.250 & 180 & $1.4 \mathrm{E} 4$ & $1.9 \mathrm{E} 3$ & $3.4 \mathrm{E} 4$ & 46.0 \\
\hline & & 2013 & 0.125 & 265 & $9.0 \mathrm{E} 3$ & $2.0 \mathrm{E} 3$ & $4.0 \mathrm{E} 4$ & 62.3 \\
\hline & & 2013 & 0.250 & 266 & $1.1 \mathrm{E} 5$ & 1019 & $4.7 \mathrm{E} 4$ & 56.0 \\
\hline \multirow[t]{2}{*}{$\mathrm{CO}_{\text {2-flux }}$} & $\mu \mathrm{g} \mathrm{m}^{-2} \mathrm{~s}^{-1}$ & 2012 & 0.0 & 143 & 110 & 7.93 & 297 & 53.7 \\
\hline & & 2013 & 0.0 & 262 & 101 & -27.0 & 661 & 93.9 \\
\hline \multirow[t]{2}{*}{${ }^{\mathrm{a}} \mathrm{NO}_{3}{ }^{-}$} & $\mathrm{mg} \mathrm{kg}^{-1}$ & 2013 & 0.125 & 30 & 14.2 & 1.06 & 47.4 & 76.4 \\
\hline & & 2013 & 0.250 & 29 & 9.96 & 1.14 & 30.2 & 65.2 \\
\hline \multirow[t]{2}{*}{${ }^{\mathrm{a}} \mathrm{NO}_{2}^{-}$} & $\mathrm{mg} \mathrm{kg}^{-1}$ & 2013 & 0.125 & 30 & 0.037 & ND & 0.12 & 72.6 \\
\hline & & 2013 & 0.250 & 29 & 0.037 & ND & 0.10 & 62.0 \\
\hline \multirow[t]{2}{*}{$\mathrm{N}_{2} \mathrm{O}-_{\text {soil }}$} & $\mu \mathrm{g} \mathrm{L}_{\text {soil air }}^{-1}$ & 2013 & 0.125 & 234 & 2.30 & 0.32 & 19.6 & 86.1 \\
\hline & & 2013 & 0.250 & 233 & 2.48 & 0.41 & 25.2 & 98.4 \\
\hline $\mathrm{N}_{2} \mathrm{O}-$ flux & $\mu \mathrm{g} \mathrm{m}^{-2} \mathrm{~s}^{-1}$ & 2013 & 0.0 & 233 & $2.9 \mathrm{E}-3$ & $-3.2 \mathrm{E}-1$ & 4.1E-1 & 1693 \\
\hline
\end{tabular}

${ }^{\mathrm{a}} \mathrm{C}_{\text {Total }}, \mathrm{C}_{\text {soluble, }} \mathrm{NO}_{3}{ }^{-}$and $\mathrm{NO}_{2}^{-}$were only measured in 2013. ND: not detected. $\mathrm{CV}$ : coefficient of variation (\%). ${ }^{\mathrm{B}}$ The values are for TBI and CM plots combined. 


\section{Figure captions}

Fig. 1. (a) Aerial view of the study site with locations of transects (coloured lines) and blocks (red rectangles), and (b) a schematic representation of a transect with its 5 sampling points.

Fig. 2. Average $\mathrm{CO}_{2}$ soil concentrations $\left(\mathrm{CO}_{2 \text {-soil }}\right)$ as influenced by (a) agricultural system (tree-based intercropping, $\mathrm{TBI}$; monoculture, $\mathrm{CM}$,) with the distance from the tree row averaged over the entire growing season; (b) agricultural system with time averaged over all treatments, and (c) the depth $(0.125$ vs $0.25 \mathrm{~m}$ ) over two growing seasons (2012 and 2013) (Error bars: LMSE).

Fig. 3. Average $\mathrm{CO}_{2}$ emission fluxes $\left(\mathrm{CO}_{2-\text { flux }}\right)$ as influenced by (a) agricultural system (tree-based intercropping, TBI; monocropping, $\mathrm{CM})$, (b) average annual $\mathrm{CO}_{2}$ fluxes $\left(\mathrm{CO}_{2 \text {-Flux }}\right)$ influenced by the distance from the tree rows and agricultural system over two growing seasons (2012 and 2013), and (c) distance from tree rows. (Error bars: LMSE).

Fig. 4. Temporal variation during 2013 of (a) $\mathrm{N}_{2} \mathrm{O}$ soil concentrations $\left(\mathrm{N}_{2} \mathrm{O}_{\text {-soil }}\right)$ as influenced by the agricultural system (tree-based intercropping, TBI; monocropping, CM) averaged over distance from the tree row and replicates; and (b) $\mathrm{N}_{2} \mathrm{O}$ emission fluxes $\left(\mathrm{N}_{2} \mathrm{O}_{\text {-Flux }}\right)$ during the 2013 season averaged over all treatments, distances from tree rows, and replicates. (Error bars: LMSE). 


\section{Canadian Journal of Soil Science}
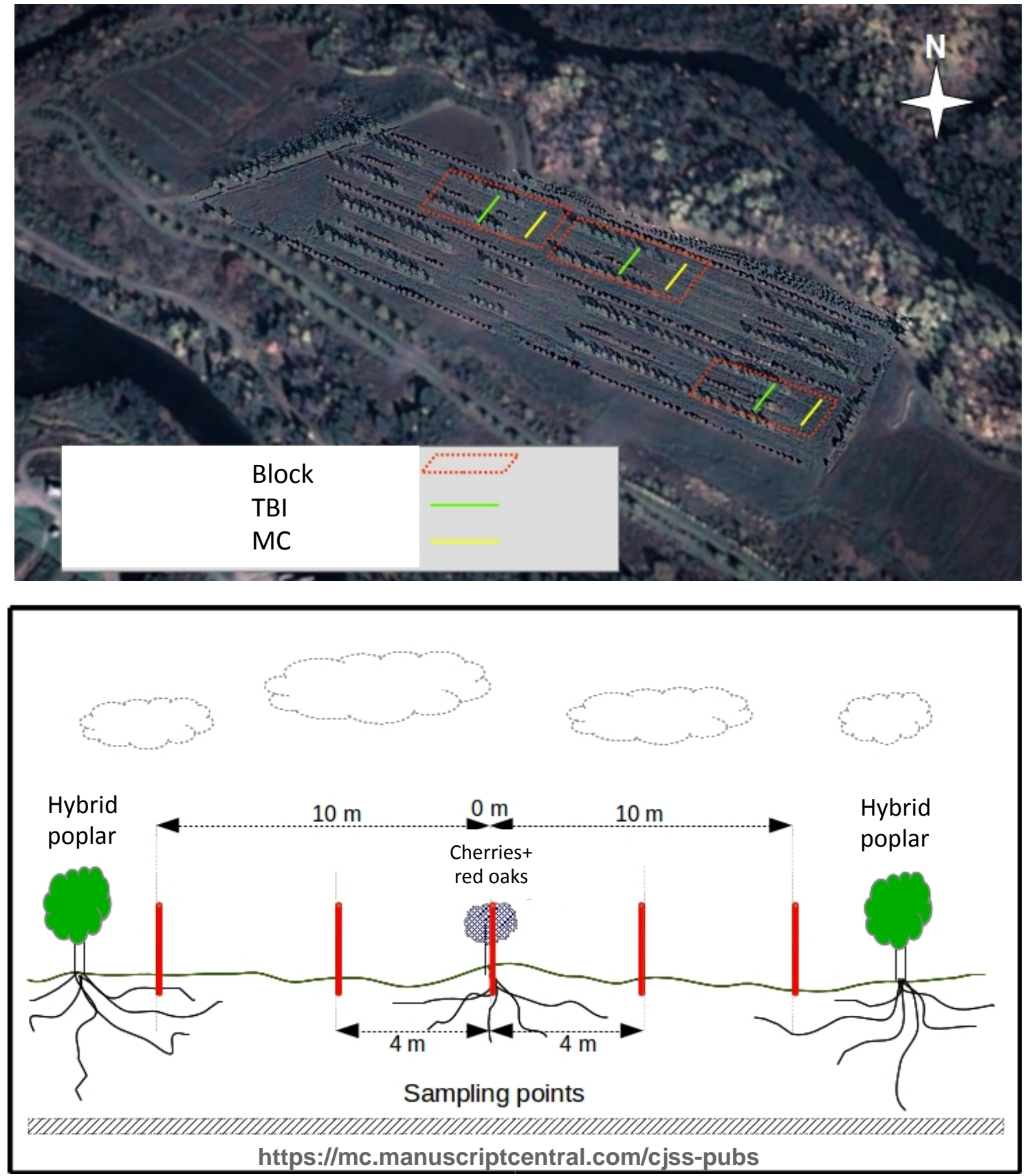

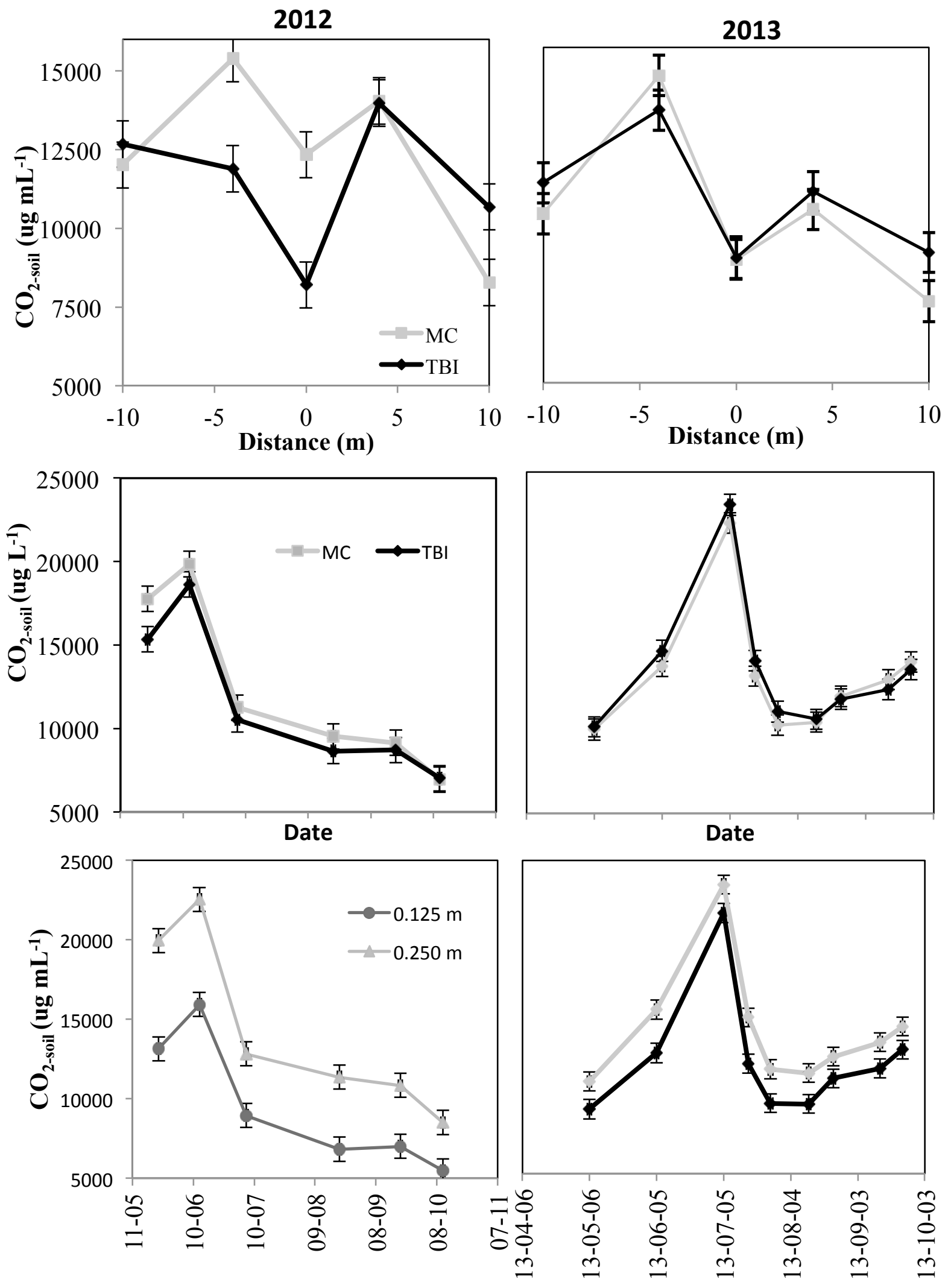

Date

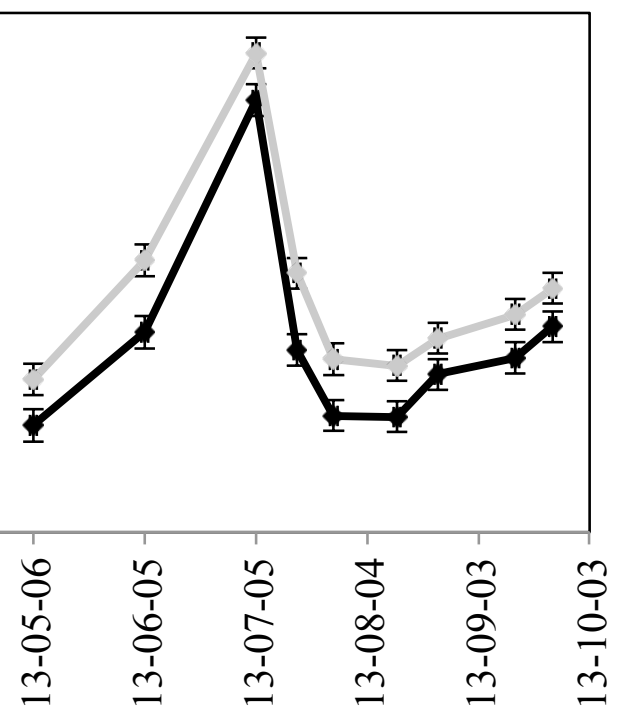

https://mc.manuscriptcentral.com/cjss-pubs

Date 
2012

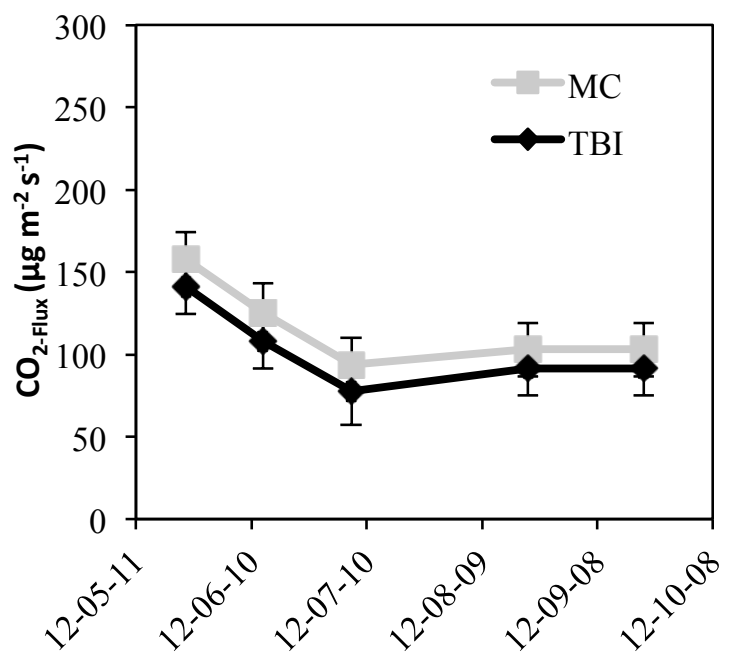

\section{Date}
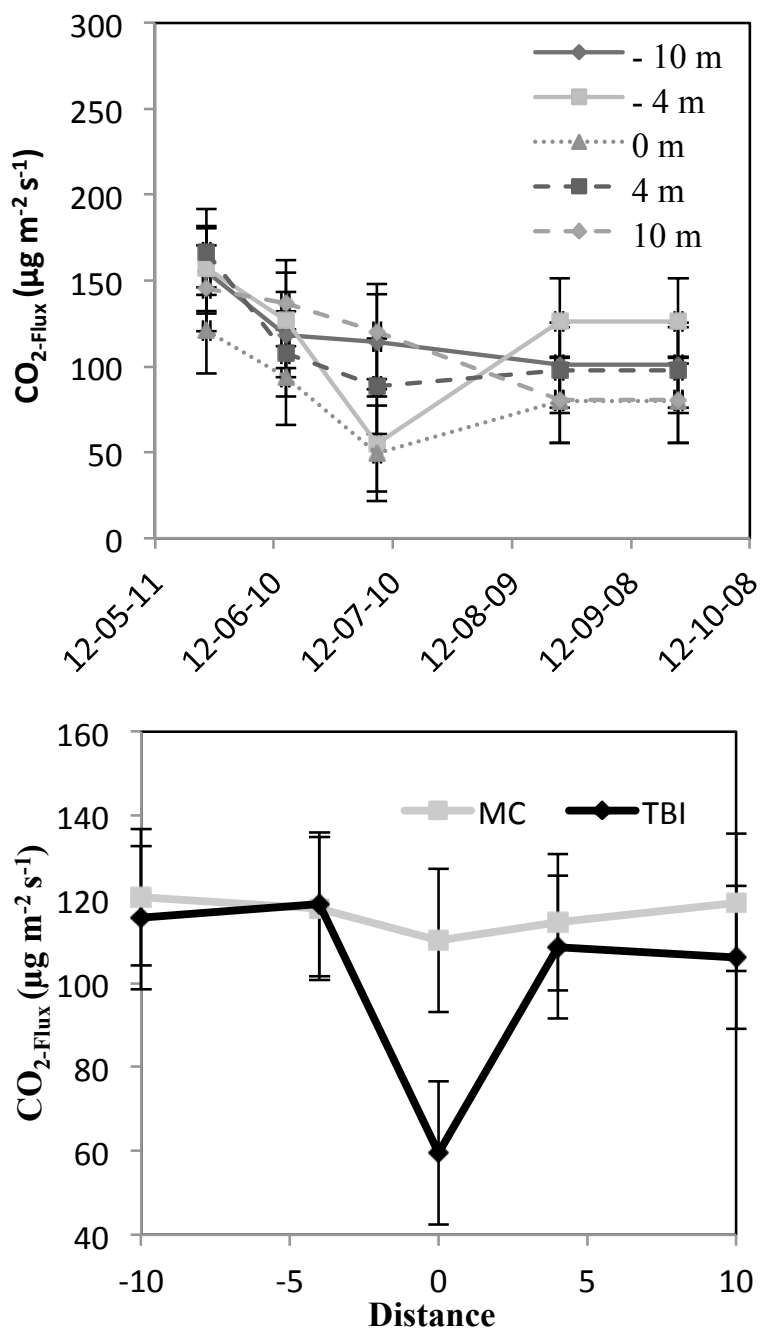

2013
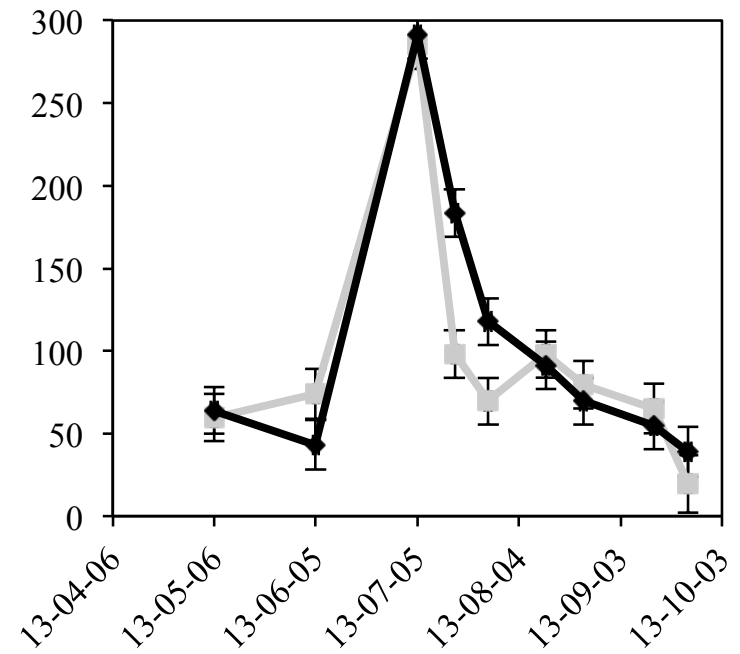

Date
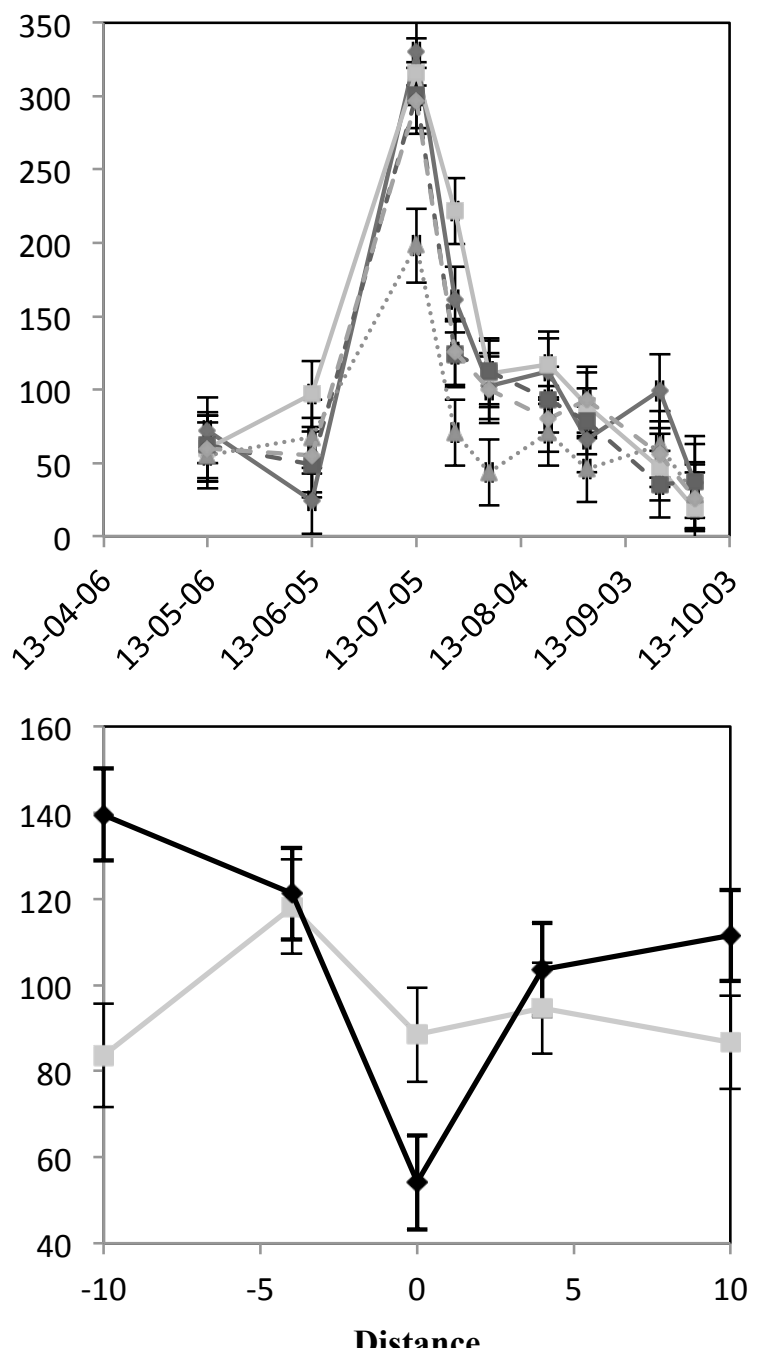

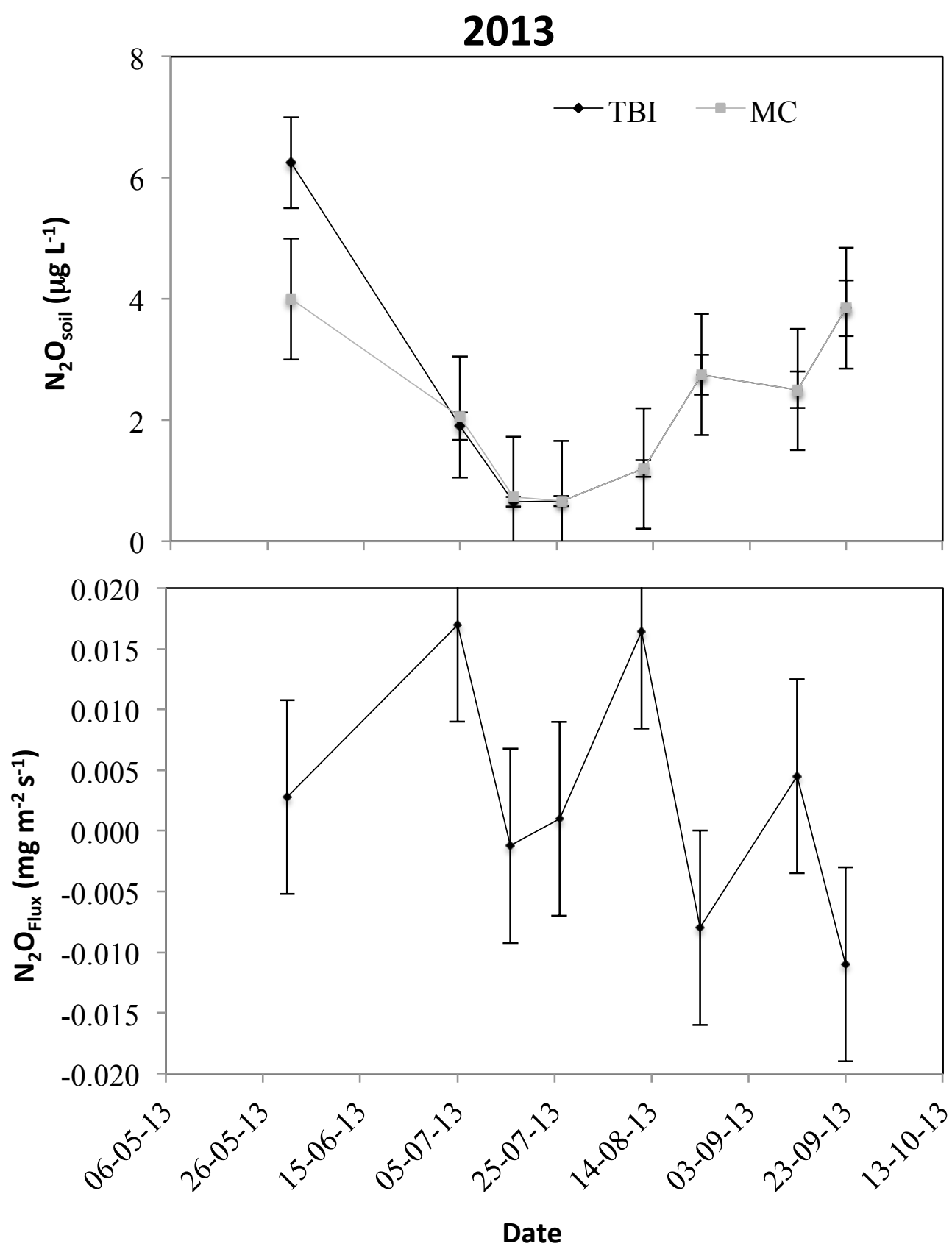
2012

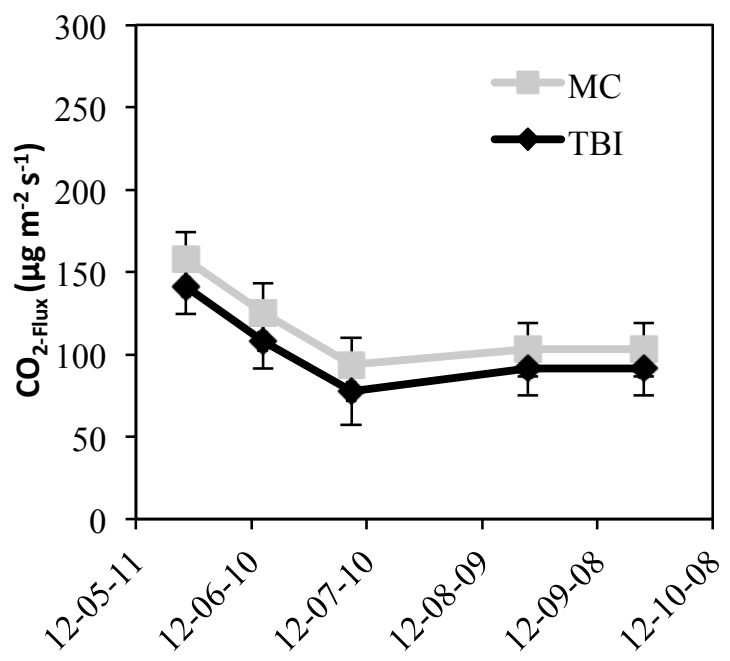

Date
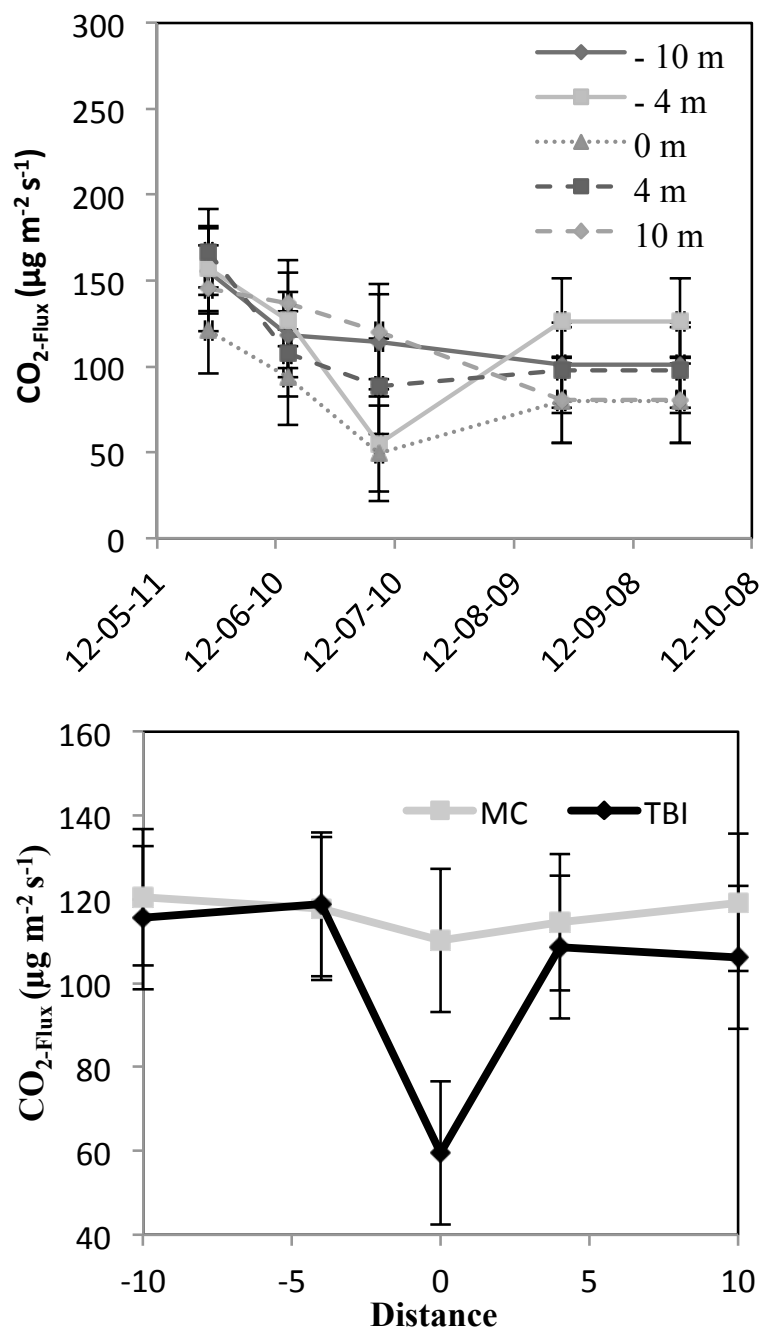

2013
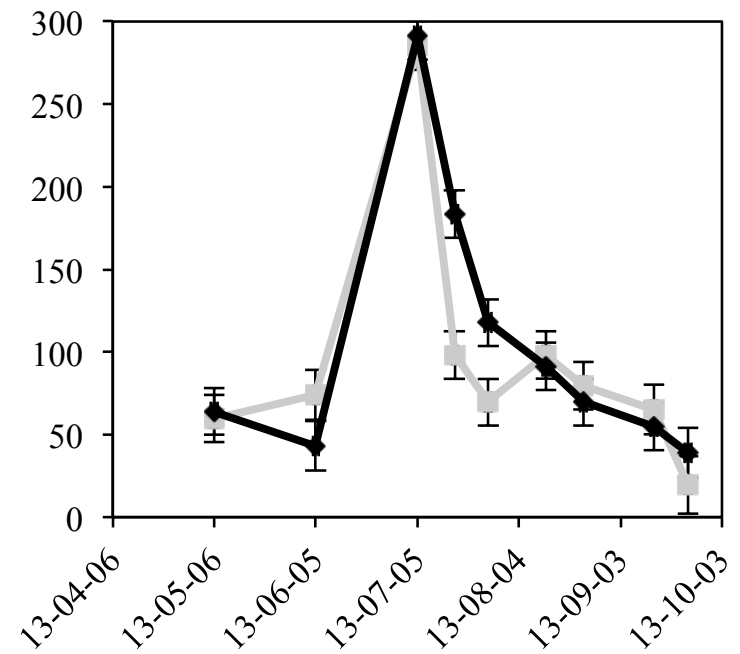

Date
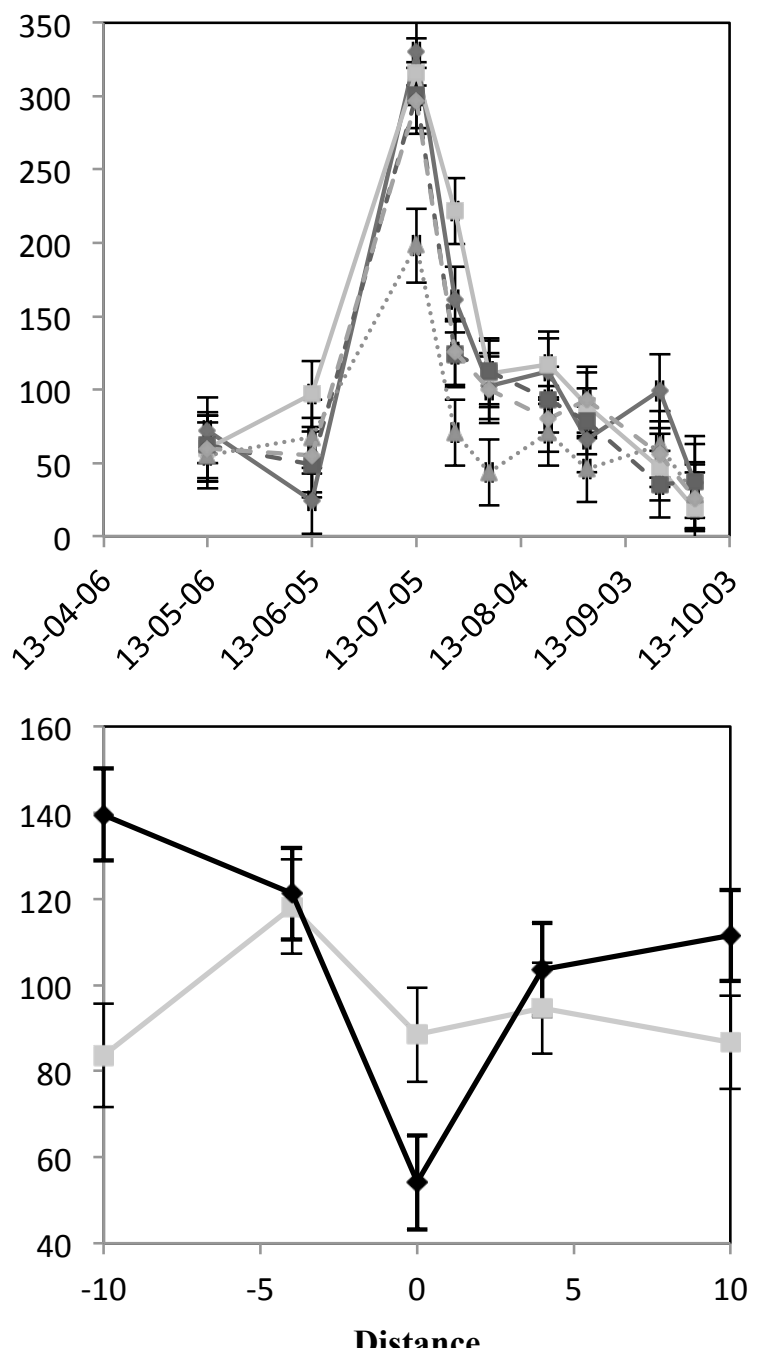

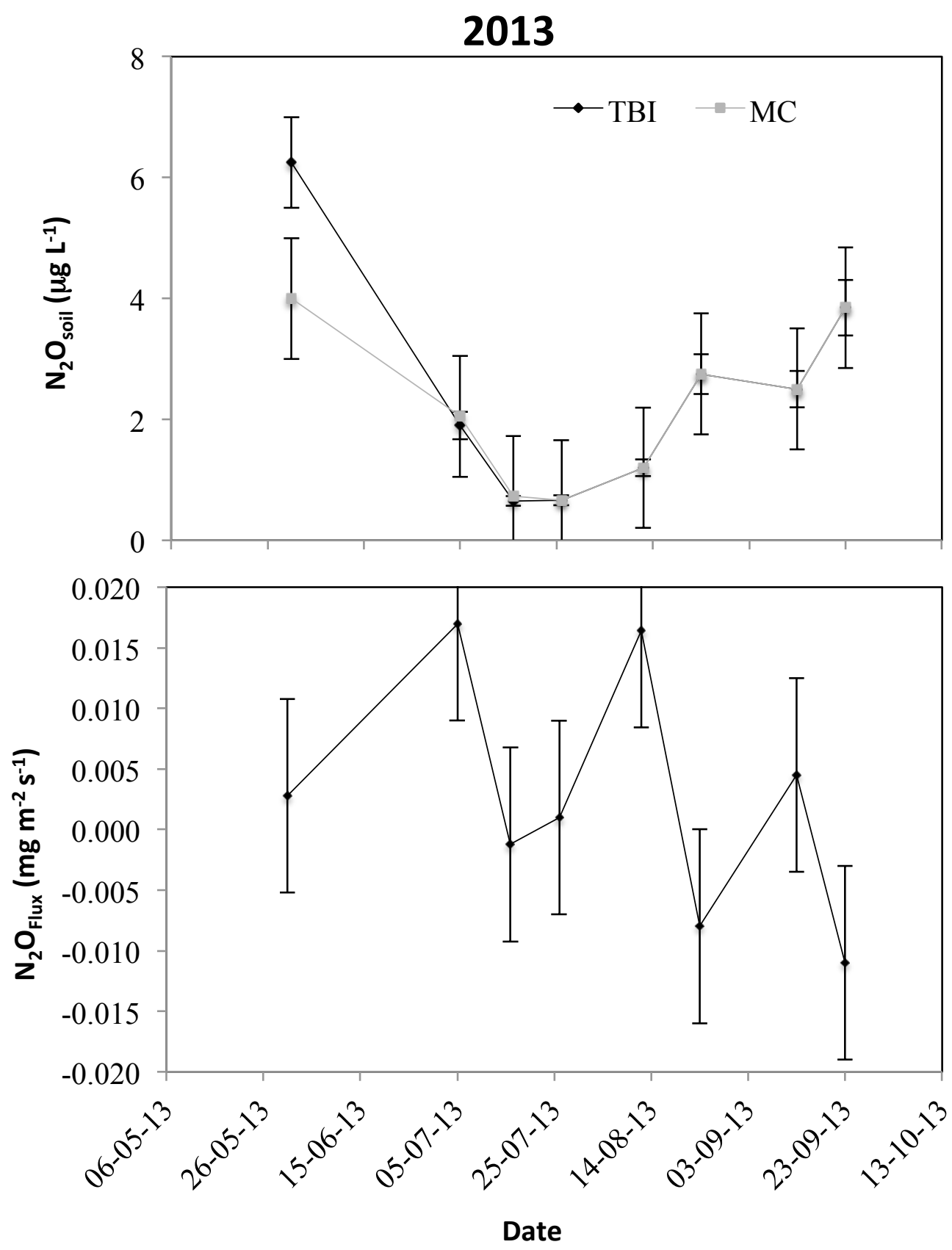